\title{
Densities of Dormant Cells of the Red Tide Flagellate Heterosigma akashiwo (Raphidophyceae) in Bottom Sediments of Northern Hiroshima Bay, Japan
}

\author{
ICHIRo IMAI* and SHIGERU ITAKURA \\ Nansei National Fisheries Research Institute, Ohno-cho, Saeki-gun, Hiroshima-ken 739-04, Japan
}

(Received January 14, 1991 - Accepted February 28, 1991)

\begin{abstract}
The distribution of dormant cells of the red tide flagellate Heterosigma akashiwo (Raphidophyceae) was investigated by the extinction dilution method in sediments of northern Hiroshima Bay where red tides of $H$. akashiwo occur almost every year. Densities of the dormant cells in sediment samples ranged from 56 to 5,950 cells $\cdot \mathrm{cm}^{-3}$ wet sediment in April 1987, and from 56 to 29,300 cells • $\mathrm{cm}^{-3}$ in March 1989. No significant relationship was observed between the number of dormant cells of $H$. akashiwo and mud content of sediment sample. High density stations of the dormant cells in sediments appeared to coincide with the areas with high concentrations of vegetative cells in water columns during the red tide season.
\end{abstract}

Key words : Heterosigma akashiwo, dormant cells, red tide, sediment

\section{Introduction}

Heterosigma akashiwo (Hada) Hada, Raphidophyceae, is known to be one of the most representative flagellates forming dense red tides. The red tides of $H$. akashiwa have been observed not only in coastal waters of Japan but also in Korea (Park et al., 1989) and in the United States (Pratt, 1959). $H$. akashiwo red tides occasionally cause mortalities of caged fish such as yellowtail, sea bass, black sea bream, right-eyed flounder, etc. In Scottish and Irish coastal waters, unidentified alga "flagellate X" have killed farmed salmon and trout (Gowen, 1987). This "flagellate $X "$ is now thought to be identical to $H$. akashiwo according to the available information on morphological features (Larsen and Moestrup, 1989). H. akashiwo had previously been confused with Olisthodiscus luteus Carter. Recently, Hara and Chihara (1987) showed that "bloom-forming" O. luteus is

* Corresponding author. identical to $H$. akashiwo.

Information on physiological characteristics of H. akashiwo had been accumulated (Iwasaki et al., 1968 ; Iwasaki and Sasada, 1969 ; Honjo and Hanaoka, 1973 ; Tomas, 1978a, 1979, 1980a ; Watanabe et al., 1982; Yamochi, 1983). Some observations were made on in situ occurrences and population growth dynamics (Iizuka and Irie, 1968; Tomas, 1980b ; Honjo and Tabata, 1985). However, investigations are scarce concerning life cycle of $H$. akashiwo including benthic resisting stage. Although Tomas (1978b) and Yamochi $(1984,1989 a)$ reported the existence of benthic stage cells in $H$. akashiwo, morphology of the benthic stage cells in sea bottom sediments has not yet been identified. Since benthic stage cells, hereafter we call as dormant cells, presumably play a key role in initiating the red tides, to know densities of dormant cells in bottom sediments is considered to be important to underatand the mechanisms for the red tide occurrences. In the present paper, the distribution of dormant cells of 


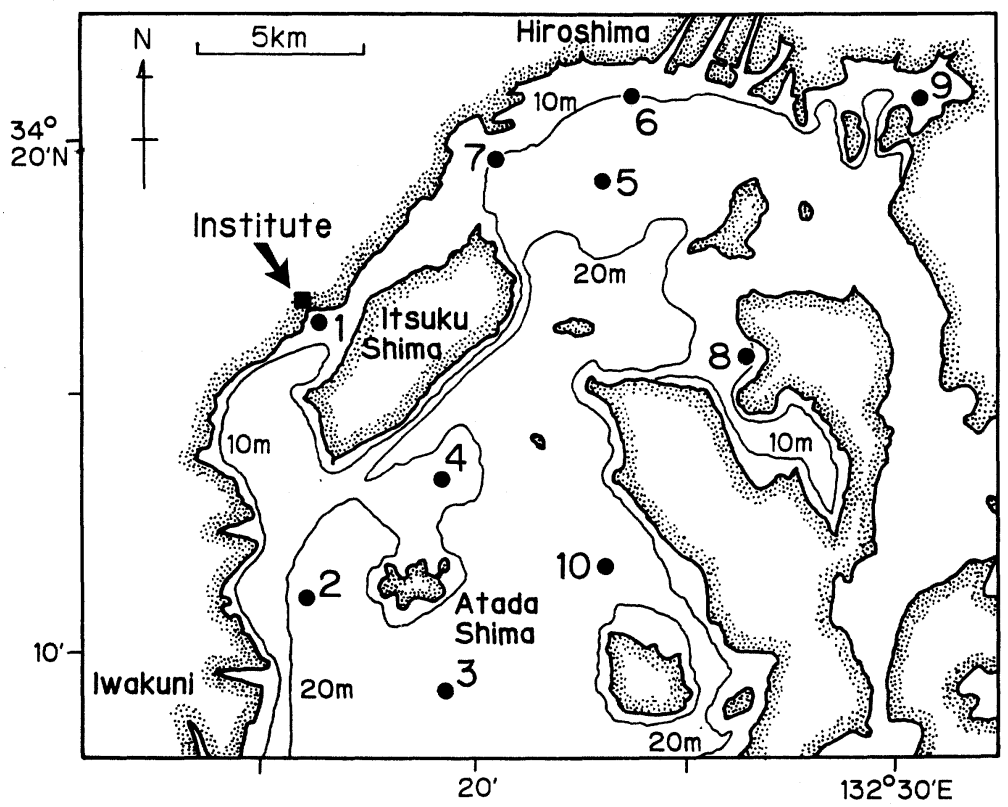

Fig. 1 Location of sediment sampling stations in northern Hiroshima Bay, the Seto Inland Sea.

H. akashiwo in sediments was investigated by the extinction dilution method (MPN method) in northern Hiroshima Bay, and its implications in the red tide occurrences were discussed.

\section{Materials and Methods}

Sediment samples were collected with a gravity core-sampler (inner diameter : $4 \mathrm{~cm}$ ) (Kimata et al., 1960) at seven stations located in northern Hiroshima Bay on 27 April 1987, and at ten stations on 29-30 March 1989 (Fig. 1). Top 1-cm depth of collected sediments (4-5 cores at each station) were taken into a plastic bottle, sealed tightly, and stored at $11^{\circ} \mathrm{C}$ in the dark afterwards.

The number of dormant cells of $H$. akashiwo in the sediment samples was enumerated by the extinction dilution method (Imai et al., 1984, Imai, 1990). The procedure of the extinction dilution method is shown in Fig. 2. An appropriate amount (1-2 g wet weight) of sediment sample was suspended in sterile modified SWM-3 culture medium (Chen et al., 1969; Itoh and Imai, 1987) at a concentration of $0.1 \mathrm{~g} \cdot \mathrm{ml}^{-1}$ in wet sediment


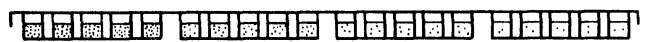

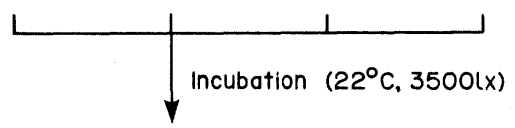

Microscopical examination of appearance of vegetative cells

Fig. 2. Procedure of the extinction dilution method for enumeration of dormant cells of $H$. akashiwo in sediment samples. 
weight. The culture medium contained $\mathrm{GeO}_{2}$ (1 $\left.\mathrm{mg} \cdot 1^{-1}\right)$ which is a specific inhibitor of diatom growth (Lewin, 1966). The suspension was sonicated for several seconds in order to segregate organic detritus. Serial 10 -fold dilutions were made with the culture medium, and then $1-\mathrm{ml}$ aliquots of diluted suspensions were inoculated into five replicate wells of disposable tissue culture cluster (48 wells, Costar). Incubation was carried out at a temperature of $22^{\circ} \mathrm{C}$ and illumination of 3,500 lux with $14 \mathrm{hL}: 10 \mathrm{hD}$ photo-cycle. The appearance of vegetative cells of $H$. akashiwo in each well was examined after the incubation period of 6-8 days using an inverted epifluorescence microscope. The well in which vegetative cells were identified was scored as positive. The most probable number (MPN) of dormant cells in the sediment sample (MPN $\cdot \mathrm{g}^{-1}$ wet sediment) was then calculated according to the statistical table (e.g. Throndsen, 1978; Itoh and Imai, 1987). The density of dormant cells per cubic centimeter wet sediment was obtained by multiplying apparent specific gravity of wet sediment. Mud content of the sediment samples in March 1989 was measured using a $63 \mu \mathrm{m}$ opening netting.

In the sediment samples of 1987 , the number of dormant cells of $\boldsymbol{H}$. akashiwo was enumerated after one month of storage period. In the samples of 1989, incubation for the enumeration by the extinction dilution method was started from the day of sampling. No vegetative cells of $H$. akashiwo were detected in water samples collected on 27 April 1987, and on 29-30 March 1989, with microscopical observations of 1-ml samples from the depths of 0,5 , and $10 \mathrm{~m}$.

\section{Results}

Figure 3 shows the densities of dormant cells of H. akashiwo in bottom sediments of northern Hiroshima Bay enumerated by the extinction dilution method. In April 1987, the dormant cells ranged from 56 (St. 3) to 5,950 cells $\cdot \mathrm{cm}^{-3}$ wet sediment (St. 1). Stations with high density of the dormant cells $\left(>1,000\right.$ cells $\left.\cdot \mathrm{cm}^{-3}\right)$ were found at Sts. 1, 2,5 and 6. These stations are located near the coast of Hiroshima (the mouth of Ohta River) and Iwakuni (the mouth of Nishiki River). In March 1989, the densities of dormant cells of $H$. akashiwo ranged between 56 (St. 10) and 29,300 cells $\cdot \mathrm{cm}^{-3}$ wet sediment (St. 5). The densities were much abundant at the mouth of Ohta River, 29,300 cells $\cdot \mathrm{cm}^{-3}$ at St. 5 , and 16,000 cells $\cdot \mathrm{cm}^{-3}$ at st. 6. Amounts of dormant cells tended to be more numerous in March 1989 than in April 1987. Although there is a fluctuation in both years, the densities of dormant cells tended to be more abundant near the coast of Honshu.

Figure 4 shows the relationship between the number of dormant cells of $H$. akashiwo and mud content of the sediment samples collected in March 1989. Mud content varied from $76 \%$ (St. 1) to $94 \%$ (St. 4). No significant relationship was found between the densities of dormant cells and mud content of sediment samples.

\section{Discussion}

The densities of dormant cells of H. akashiwo in bottom sediments of northern Hiroshima Bay were 56-5,950 cells $\cdot \mathrm{cm}^{-3}$ in April 1987, and 56-29,300 cells $\cdot \mathrm{cm}^{-3}$ in March 1989. In Osaka Bay, Yamochi (1989b) enumerated the number of benthic cells (dormant cells) of $H$. akashiwo in bottom sediments of 21 stations by similar method, and obtained the data of $5-270$ cells $\cdot \mathrm{g}^{-1}$ wet sediment in June 1986, and 27-5,400 cells $\cdot \mathrm{g}^{-1}$ in October 1987. The distribution of dormant cells of $H$. akashiwo was also measured in Suo-Nada, western Seto Inland Sea, and the number ranged between 20 and 790 cells $\cdot \mathrm{g}^{-1}$ wet sediment in autumn of 1987 (K. Terada, personal communication). Compared the data of northern Hiroshima Bay with Osaka Bay and Suo-Nada, the densities of dormant cells in April 1987 are about in similar range. On the other hand, in March 1989, the maximum number in northern Hiroshima Bay was 

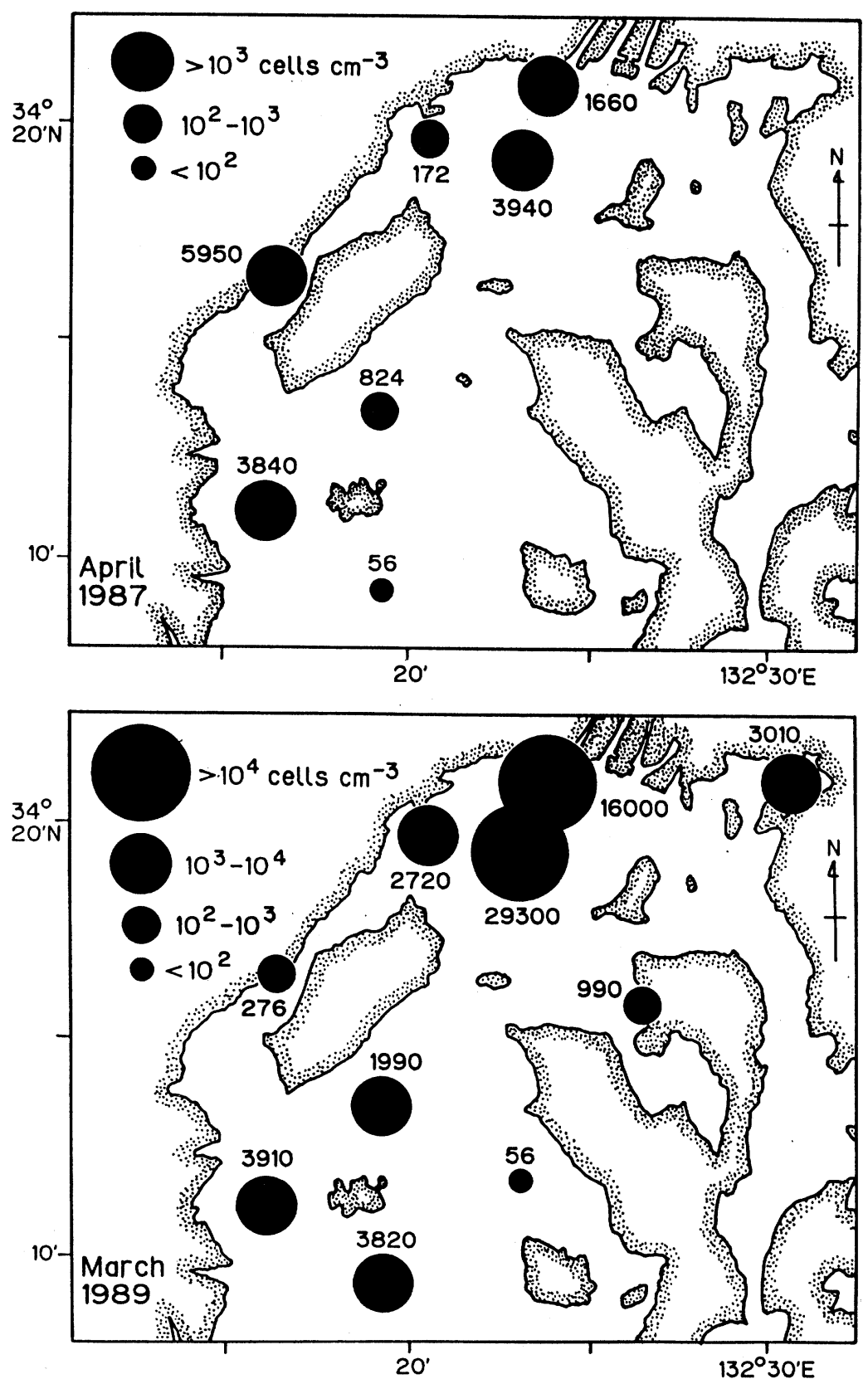

Fig. 3. Densities of dormant cells of H. akashiwo in bottom sediments of northern Hiroshima Bay, enumerated by the extinction dilution method. Numerals indicate the number of the dormant cells per cubic centimeter wet sediment. 


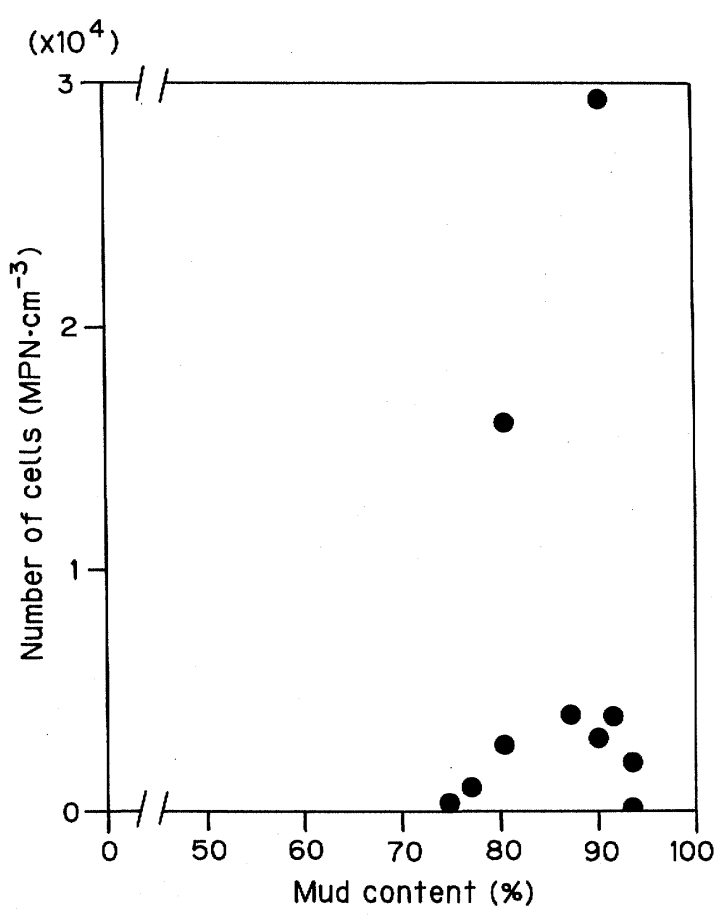

Fig. 4. Relationship between the number of dormant cells of $\boldsymbol{H}$. akashiwo and mud content of the sediment samples.

one order of magnitude higher value than that in Osaka Bay and Suo-Nada.

High density stations of dormant cells of $H$. akashiwo were found in the coastal area of Honshu such as the mouth of Ohta River. High density stations in bottom sediments appeared to coincide with the areas with high concentrations of vegetative cells in water columns during the red tide season. And no relationship was observed between the density of dormant cells and mud content of sediment sample. In the case of the toxic dinoflagellate Alexandrium excavatum (Gonyaulax excavata), howaver, White and Lewis (1982) reported that dense seed bed areas were found in a zone of fine brown sediment in Bay of Fundy, Canada. Thus, it is an important problem to understand the effects of hydrographic and sedimentary processes on dense seed bed formation in $H$. akashiwo.

In recent years, it has been well documented that the presence of cysts (dormant cells) in bottom sediments encourages the survival of species and initiation of blooms in rather many dinoflagellates including toxic species (Wall, 1971; Anderson et al., 1983; Sako et al., 1985). In raphidophycean flagellates, the morphology was identified in the cysts of Chattonella (C. antiqua and C. marina) (Imai and Itoh, 1986, 1988) and Fibrocapsa japonica (Yoshimatsu, 1987) from bottom sediments of the Seto Inland Sea. The studies concerning the ecophysiological aspects of the cysts of Chattonella (Imai et al., 1986, 1989; Imai and Itoh, 1987; Imai, 1990) strongly suggested the importance of cysts in initiating the summer red tides in the Seto Inland Sea. Yamochi $(1984,1989 a, b)$ also suggested the significant role of "benthic cells" in bloom formation of $H$. akashiwo in Osaka Bay.

The present study revealed the existence of abundant dormant cells of $\boldsymbol{H}$. akashiwo in bottom sediments of northern Hiroshima Bay, where $H$. akashiwo red tides occur almost every year. Studies are in progress concerning the seasonal changes in germinability of dormant cells in sediments and vegetative cell concentrations in water columns of northern Hiroshima Bay. We have recently succeeded in identifying the morphology of the cyst of $H$. akashiwo from the bottom sediments of northern Hiroshima Bay (Imai et al., in preparation). The detailed results of the observations will be published elsewhere.

\section{Acknowledgements}

We are grateful to Dr. K. Itoh, National Research Institute of Aquaculture, Fisheries Agency, for his helpful advice and encouragement during the course of this study. The present study was supported in part by a grant from the Environment Agency of Japan.

\section{References}

Anderson, D.M., S.W. Chisholm and C.J. Watras, 1983. Importance of life cycle events in the popu- 
lation dynamics of Gonyaulax tamarensis. Mar. Biol., 76, 179-189.

Chen, L.C.M., T. Edelstein and J. McLachlan, 1969. Bonnemaisonia hamifera Hariot in nature and in culture. J. Phycol., 5, 211-220.

Gowen, R.J., 1987. Toxic phytoplankton in Scottish coastal waters. Rapp. P.-.v. Réun. Cons. int. Explor. Mer, 187, 89-93.

Hara, Y. and M. Chihara, 1987. Morphology, ultrastructure and taxonomy of the raphidophycean alga Heterosigma akashiwo. Bot. Mag., Tokyo, 100, $151-163$

Honjo, T. and T. Hanaoka, 1973. Studies on the mechanisms of red tide occurrence in Hakata Bay II. General features of red tide flagellate, Heterosigma sp. Bull. Plankton Soc. Japan, 19, 75-81. (In Japanese with English abstract).

Honjo, T. and K. Tabata, 1985. Growth dynamics of Olisthodiscus luteus in outdoor tanks with flowing coastal water and in small vessels. Limnol. Oceanogr., 30, 653-664.

Iizuka, S. and H. Irie, 1968. Discoloration phenomena caused by microalgae in Nagasaki Pref. in 1966 and ecology of causative organism, Olisthodiscus. Bull. Fac. Fish. Nagasaki Univ., No. 26, 25-35. (In Japanese with English abstract).

Imai, I., 1990. Physiology, morphology, and ecology of cysts of Chattonella (Raphidophyceae), causative flagellates of noxious red tides in the Inland Sea of Japan. Bull. Nansei natl. Fish. Res. Inst., No. 23, 63-166. (In Japanese with English abstract).

Imai, I. and K. Itoh, 1986. A preliminary note on the cysts of Chattonella (Raphidophyceae), red tide flagellates, found in bottom sediment in SuoNada, western Seto Inland Sea, Japan. Bull. Plankton Soc. Japan, 33, 61-63. (In Japanese with English abstract).

Imai, I. and K. Itoh, 1987. Annual life cycle of Chattonella spp., causative flagellates of noxious red tides in the Inland Sea of Japan. Mar. Biol., 94, 287-292.

Imai, I. and K. Itoh, 1988. Cysts of Chattonella antiqua and C. marina (Raphidophyceae) in sediments of the Inland Sea of Japan. Bull. Plankton Soc. Japan, 35, 35-44.

Imai, I., K. Itoh and M. Anraku, 1984. Extinction dilution method for enumeration of dormant cells of red tide organisms in marine sediments. Bull. Plankton Soc. Jpan, 31, 123-124.

Imai, I., K. Itoh and M. Anraku, 1989. Dormancy and maturation in the cysts of Chattonella spp. (Raphidophyceae), red tide flagellates in the Inland Sea of Japan. In : Red tides : Biology, environmental science, and toxicology, (edited by $\mathrm{T}$. Okaichi, D.M. Anderson and T. Nemoto) pp. 289-
292. Elsevier, New York.

Imai, I., K. Itoh, K. Terada and M. Kamizono, 1986. Distribution of dormant cells of Chattonella (Raphidophyceae) and occurrence of summer red tide in Suo-Nada, western Seto Inland Sea. Bull. Japan. Soc. sci. Fish., 52, 1665-1671. (In Japanese with English abstract).

Itoh, K. and I. Imai, 1987. Rafido so (Raphidophyceae). In: A guide for studies of red tide organisms, (edited by Japan fisheries resource conservation association) pp. 122-130. Shuwa, Tokyo. (In Japanese).

Iwasaki, H., T. Fujiyama and E. Yamashita, 1968. Studies on the red tide dinoflagellates-I. On Entomosigma sp. appeared in coastal area of Fukuyama. J. Fac. Fish. Anim. Husb. Hiroshima Univ., 7, 259-267. (In Japanese with English abstract).

Iwasaki, H. and K. Sasada, 1969. Studies on the red tide dinoflagellates-II. On Heterosigma inlandica appeared in Gokasho Bay, Shima Peninsula. Bull. Japan. Soc. sci. Fish., 35, 943-947. (In Japanese with English abstract).

Kimata, M., A. Kawai and Y. Ishida, 1960. The method for sampling of marine bottom muds. Bull. Japan. Soc. sci. Fish., 26, 1227-1230. (In Japanese with English abstract).

Larsen, J. and $\varnothing$. Moestrup, 1989. Guide to toxic and potentially toxic marine algae, $61 \mathrm{pp}$. Fish inspection service, Ministry of Fisheries, Copenhagen.

Lewin, J.C., 1966. Silicon metabolism in diatoms. V. Germanium dioxide, a specific inhibitor of diatom growth. Phycologia, 6, 1-12.

Park, J.S., H.G. Kim and S.G. Lee, 1989. Studies on red tide phenomena in Korean coastal waters. In: Red tides: Biology, environmental science, and toxicology, (edited by T. Okaichi, D.M. Anderson and T. Neomoto) pp. 37-40. Elsevier, New York.

Pratt, D.M., 1959. The phytoplankton of Narragansett Bay. Limnol. Oceanogr., 4, 425-440.

Sako, Y., Y. Ishida, H. Kadota and Y. Hata, 1985. Excystment in the freshwater dinoflagellate Peridinium cunningtonii. Bull. Japan. Soc. sci. Fish., 51, 267-272.

Throndsen, J., 1978. The dilution-culture methood. In : Phytoplankton manual, (edited by A. Sournia) pp. 218-224. Unesco, Paris.

Tomas, C.R., 1978a. Olisthodiscus luteus (Chrysophyceae) I. Effects of salinity and temperature on growth, motility and survival. J. Phycol., 14, 309-313.

Tomas, C.R., 1978b. Olisthodiscus luteus (Chrysophyceae) II. Formation and survival of a benthic stage. J. Phycol., 14, 314-319. 
Tomas, C.R., 1979. Olisthodiscus luteus (Chrysophyceae) III. Uptake and utilization of nitrogen and phosphorus. J. Phycol., 15, 5-12.

Tomas, C.R., 1980a. Olisthodiscus luteus (Chrysophyceae) IV. Effects of light intensity and temperature on photosynthesis, and cellular composition. J. Phycol., 16, 149-156.

Tomas, C.R., 1980b. Olisthodiscus luteus (Chrysophyceae) V. Its occurrence, abundance and dynamics in Narragansett Bay, Rhode Island. J. Phycol., 16, 157-166.

Wall, D., 1971. Biological problems concerning fossilizable dinoflagellates. Geoscience and Man, 3, $1-15$.

Watanabe, M.M., Y. Nakamura, S. Mori and S. Yamochi, 1982. Effects of physico-chemical factors and nutrients on the growth of Heterosigma akashiwo Hada from Osaka Bay, Japan. Jpn. J. Phycol., 30 : 279-288.

White, A.W. and C.M. Lewis, 1982. Resting cysts of the toxic, red tide dinoflagellate Gonyaulax excavata in Bay of Fundy sediments. Can J. Fish. aquat. Sci., 39, 1185-1194.
Yamochi, S., 1983. Mechanisms for outbreak of Heterosigma akashiwo red tide in Osaka Bay, Japan. Part 1. Nutrient factors involved in controlling the growth of Heterosigma akashiwo Hada. J. oceanogr. Soc. Japan, 39, 310-316.

Yamochi, S., 1984. Mechanisms for outbreak of Heterosigma akashiwo red tide in Osaka Bay, Japan. Part 3. Release of vegetative cells from bottom mud. J. oceanogr. Soc. Japan, 40, 343348.

Yamochi, S., 1989a. Mechanisms for outbreak of Heterosigma akashiwo red tide in Osaka Bay, Japan. Bull. Osaka Pref. Fish. exp. Stn., No. 8, 1110. (In Japanese with English abstract).

Yamochi, S., 1989b. Distributions of benthic cells of Skeletonema costatum and Heterosigma akashiwo in Osaka Bay. Bull. Plankton Soc. Japan, 36, 47-51. (In Japanese with Engilsh abstract).

Yoshimatsu, S., 1987. The cysts of Fibrocapsa japonica (Raphidophyceae) found in bottom sediment in Harima-Nada, eastern Inland Sea of Japan. Bull. Plankton Soc. Japan, 34, 25-31. (In Japanese with English abstract). 